\title{
Technical Report on Reclamation of Small Scale Surface Mined Lands in Ghana: A Landscape Perspective
}

\author{
J.B.K Asiedu \\ Department of Crop Science, University of Cape Coast. Cape Coast, Ghana \\ *Corresponding author: klartlands@yahoo.com
}

Received December 30, 2012; Revised February 18, 2013; Accepted April 05, 2013

\begin{abstract}
Small scale mining activities which involve surface mining is an acceptable means of mineral exploitation in Ghana but has serious environmental consequences. Although a number of laws and research papers have been written on restoration after a piece of land has been mined, not much detail is provided on the actual processes involved. This review paper attempts a look at the process of restoration with projections on cost of restoration. Although it is based on activities at a predominantly farming community like Akyem Hemang in the Fanteakwa district of the Eastern region of Ghana, the principles involved will be applicable to other mining communities in the tropics. The paper looks at aspects of surface mining popular in rural areas of Ghana and attempt to explain the process of restoration with suggestions on how to measure success and how to involve affected communities to safe guard and ensure the success of the programme. A licensed concession can be as small as 3acres or as large as 25acres and can be mined for 3-5 years after which the land should be reclaimed to a productive state. The reclamation process, after field establishment should last for at least 5years to determine success. Small scale mining is defined as the use of rudimentary implements as well as the more sophisticated mining operating at a relatively low level of production with limited capital investment. It is carried out in rural farming communities and is popular with itinerant poorly educated people and usually results in severe deterioration to the environment, especially, crop land; posing serious health risks to communities in which it is carried out. The deterioration results from the destruction of vegetal cover and excavation of the overburden to assess the mineral bearing soil. Where farm lands or forested lands have been affected, a combination of natural and artificial reclamation is recommended. The process of reclamation should be planned and begins when topsoil at the mined site is removed to store separately from the subsoil and over-burden at the pre-mining stage. Topsoil however cannot be stored for too long as the quality deteriorates with time. Depending on the depth of excavation, restoration should involve importation and replacement of subsoil to a depth of $600 \mathrm{~mm}-900 \mathrm{~mm}$ spread in $150 \mathrm{~mm}$ layers, and left to settle naturally for a period of 3 -6months. When the land is sufficiently settled, topsoil mixed with manure should be laid over the subsoil to a depth of $150 \mathrm{~mm}$ minimum after settling. This is followed by sowing of nitrogen fixing leguminous green manure by broadcasting to provide the first blanket of vegetative cover to protect the soil from the direct effect of the elements. Although Crotalaria juncea (Sunnhemp) is highly recommended nitrogen fixing leguminous annual with high biomass production for highly degraded land, other area-specific nitrogen fixing plants can be recommended by the area agricultural extension officer. About 60days after sowing of the green manure cover crop, when it is in bloom, it is smothered and worked into the soil. Seedlings of both local and exotic tree plants can then be established on the land after pegging and holing to 563seedlings per acre. The reclaimed land should be maintained and managed by maintaining a balance between introduced exotic tree seedlings and native sprouted tree seedlings by weeding, staking, and occasional pruning for at least 5years before any assessment for the success of the reclamation can be done. The estimated cost for reclamation of 1acre of mined land excavated to a depth of $900 \mathrm{~mm}$ is about US\$52,419.33 (Gh\$101,000), inclusive of 2-3\% for maintenance.
\end{abstract}

Keywords: galamsey, ground cover, organic manure, reclamation, small scale mining, topsoil

\section{Introduction}

The negative impact of mining activities on the environment is well documented, more especially small scale mining which has also become popular with the advent of modern technological advances in the extractive industry [20]. Small scale mining involves surface mining [7] and includes both artisanal mining which involve the use of rudimentary implements as well as the more sophisticated mining operating at a relatively low level of production with limited capital investment [4]. Smallscale surface mining is used to mine a number of minerals in Ghana, the main one being gold which makes up about $90 \%$ of production and diamond [3]. 
The industry brings a number of benefits including employment generation, revenue generation, support for rural livelihoods, a means for quick wealth, with a low investment cost compared with large scale mining $[12,20]$. Although statistics on the number of people employed by the industry in Ghana has not been very reliable, some estimates puts it at about 100,000 legally employed and 50,000-80,000 illegally employed, also called 'Gallamsey' [20].

Small-scale mining activities can be used to serve as a catalyst for the development of rural economies and for wider investment in the economy [3,12], especially, as a poverty driven activity which is popular in remote rural areas of the country [4]. Although the industry is predominantly local-owned [3] employing largely itinerant, poorly educated people with little employment alternatives [4], it is believed that the future of the mining industry lies with it [7]. It is however less cost effective considering the man hours invested in extraction [20], but this can be improved considerably if operators become fully aware of the cost of restoration to the environment. Although a number of laws and research papers have been written to protect the environment from mining activities in Ghana, not much detail is provided on the actual process involved to achieve restoration. This paper attempts a look at the process of restoration with projections on cost of restoration after a piece of land has been exhaustively mined. Although is based on activities at a predominantly farming community like Akyem Hemang in the Fanteakwa district of the Eastern region of Ghana, the principles involved will be applicable to other mining communities in the tropics and can serve as a guide to the industry and policy makers.

\section{What the Mining Law Requires}

A new Mineral and Mining Act, 2006 (Act 703) has been passed in Ghana. The law identifies small-scale mining and defines it as 'mining by any method not involving substantial expenditure by an individual or group of persons not exceeding nine (9) in number or by a cooperative society made up of ten (10) or more persons' [4]. It requires that people engaged in small scale mining are licensed to mine either from the Minerals Commissions' concessions or from a Mining company with a concession right [20] in areas designated as suitable for small scale mining [3]. A small scale operator or miner will be licensed to mine a designated plot of land not exceeding 25 acres for a period of 3-5years [12]. Reference [4] explains that license is granted to Ghanaians aged 18years and above and is in three categories. The first category is license for a 3acre plot size for one person or group of persons not exceeding 4 in number. The second category is for a 5acre concession for any group of persons not exceeding nine (9) in number, while the third covers 25acres concession for a cooperative society made of ten (10) or more persons and registered companies.

The law requires a licensed operator to produce environmental impact assessment for his activities which must demonstrate how the mining activities has been planned in an environmentally sensitive manner, and that appropriate mitigative measures and safeguards have been integrated into the design to protect the environment. This should be accompanied by a quality reclamation plan which should specify among others how topsoil will be preserved, slopes will be stabilized and restored, progressive reclamation will be carried out, and how revegetation will be effected [20]. The concessioner will be expected to post a pre-mining financial assurance or security in the form of cash, letters of credit, surety bonds or trust fund to cover the cost of environmental damage [18]. This is what is used to reclaim the mined site in case of default and where the community or regulatory authority is satisfied that reclamation has been effective, a closure certificate is issued, allowing refund of whatever amount was awarded for reclamation. Thus, although there are provisions in the law on mine closure, it is not sufficiently detailed, clearly defining set aside funds to meet clear and comprehensive reclamation and other mine closure obligations [3].

\section{How Small-scale Mines Operate}

A person or group of persons, also called Operator, may obtain license to mine a piece of land. The Operator may hire labourers or groups of workers (5-200 groups) called tributers who consist of 5-10 workers each to mine the plot. The arrangement is for the tributers to keep twothirds of the proceeds from the gold profit, while the remaining goes to the operator or concessionaire [12,20].

Surface mining is preferred in situations where mineral deposits occur close to the surface of the soil or form part of surface deposits to allow for easy access [7]. Different mining methods are used by small scale miners. This includes panning, sluicing, open pit and strip mining methods, dredging and hydraulic mining in riverbeds. With the exception of hydraulic mining, all the other methods are in use in Ghana. Panning involves digging up semi-consolidated river alluvium and washing it in dishes with a flow of water so that a concentrated gold or diamond is left behind. Sluice mining involves shoveling the ore manually or mechanically into the head of an elongated sluice box. Water is directed through the sluice box trapping the fine heavy minerals. Strip mining is carried out in areas where the land surface and deposits are relatively horizontal, although it can be used in hilly areas too. Dredging is undertaken in rivers, ponds, lakes, seashores. Although all the methods results in disturbances to the environment, strip mining causes the most substantial disturbance and is the most popular in Ghana.

\section{Major Challenges Posed by the Industry}

A major challenge posed by surface mining is environmental [9], specifically, land degradation and mercury pollution [12]. Unfortunately, it is often erroneously assumed that small scale miners operate on small pieces of land, and that their operations has little effect [7] and should essentially be left alone. However, 
considering the number of people engage by the industry [19], the combined effect of their activity on the environment cannot be underestimated. Reference [18] considers surface mining as the greatest agent of land degradation and destruction, infesting about $13 \%$ of the total forested land of $240,000 \mathrm{~km}^{2}$ in Ghana and resulting in excavations to depths of up to $3 m[4,20]$.

Degradation results in significant threat to biodiversity conservation with devastating effect on soil ecosystems; leading to increased soil temperature, loss and depletion of soil nutrients, erosion, changes in topography, hydrology $[5,18]$ destroying ecosystems with its unique habitats, fauna and flora, making the land less productive. This is more important as majority of the mining concessions are found in and around forests, agricultural lands and human settlements; resulting in competition for land and depriving farmers access to land [18]. This is better appreciated where miners leave in their wake unstable piles of waste, abandoned excavations, vast stretches of barren land (Figure 1), un-reclaimed excavated pits sometimes filled with water; which become death traps as well as breeding grounds for mosquitoes [4,12,20] as result of which farmers have had to abandon their farms and communities rendered unhealthy, unsafe and unproductive.

Mercury pollution is the second important environmental concern. Mercury when used in the extraction process forms an amalgam and turns into a stable methylated compound which when ingested, inhaled or absorbed by fauna and flora become toxic to man and the environment [12].

Nevertheless, [4] points out that although small scale surface mining affects the environment, in most cases, the effect is minimal. It is rather the illegal small scale surface miners whose operations pose the real danger to the environment.

\subsection{The Mining Process}

In mining a plot of land the small scale miner strips the land of vegetation, remove the topsoil to heap, and digs out subsequent layers of soil, usually gravel, to a depth of about $1 \mathrm{~m}$ for gold mining (Figure 1) concessions or 3$3.6 \mathrm{~m}$ for diamond mining plots [20]. In most cases however, the entire area is bulldozed off to clear both vegetation and soil (overburden). The overburden which form a soil heap is stockpiled for later us to reclaim the land [7]. After the vegetation has been cleared, topsoil should be removed and stored separately from the subsoil and overburden. This is very important as the mixing of the subsoil, which usually is less fertile, with the top soil will affect the fertility of the topsoil and its effectiveness in any future reclamation effort [13]. This however is hardly done in any of the mining communities I have visited in Ghana either because the topsoil layer is too thin or the miners do not really see the need to waste so much manual labour on such an exercise. Common tools and equipment used include pick axe, axe, sluice boxes, shovels, water pumping machine, and under a more mechanized operation bulldozers, backhoe. For well organized groups, work stations are established close to a source of water where the final processing is done [12].
After the overburden has been removed, the rock bearing mineral is dug out to extract the ore [20]. The ore is crashed by hand or machined before it is put in storage sacs or sheds (Figure 2).

The crushed ore then undergoes primary and secondary grinding in preparation for washing (Figure 3) in a water source (like a river) where the finely crushed sediments is spread on a blanket or hand washed to separate valuable gold particles from the chuff. The sediment is then panned using mercury and the resultant amalgam roasted on open fire, usually, charcoal $[4,7,12]$. Mercury is thus very important in the concentration and extraction of the gold from the ore in small scale mining. The chuff may be either be sold in truck loads for further processing or as a raw material for building construction (Figure 4).

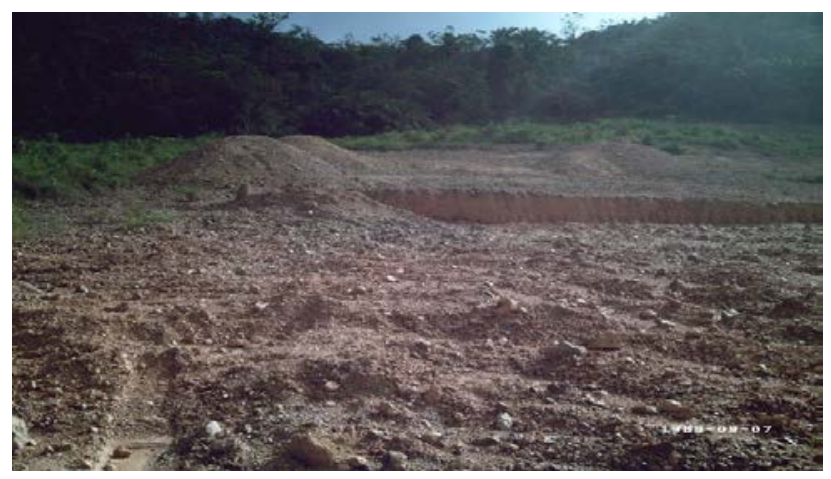

Figure 1. Part of a stretch of land cleared of vegetation and overburden for surface mining activities in a mining community in Ghana

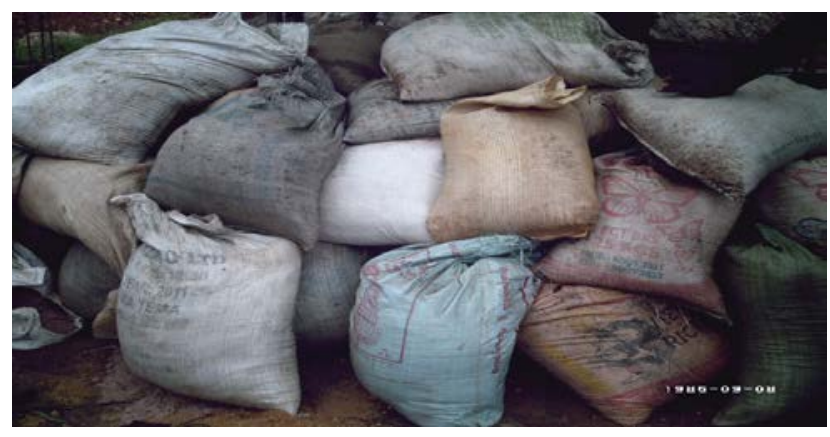

Figure 2. Sac loads of ore ready to be extracted

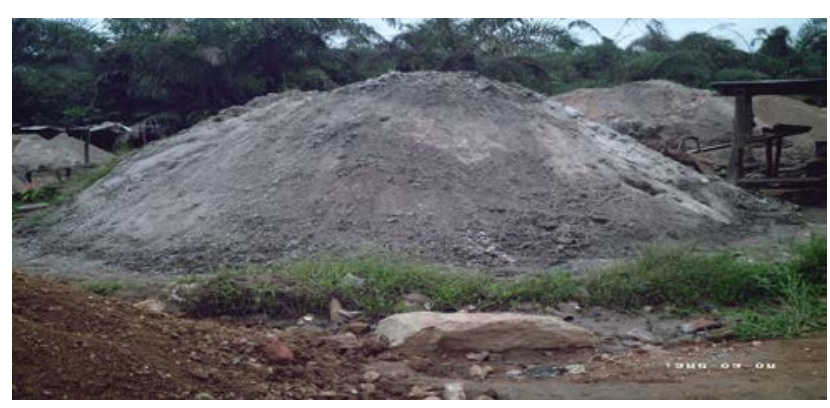

Figure 3. Crashed gold bearing ore ready to be processed. Background, spent ore and processing machine 


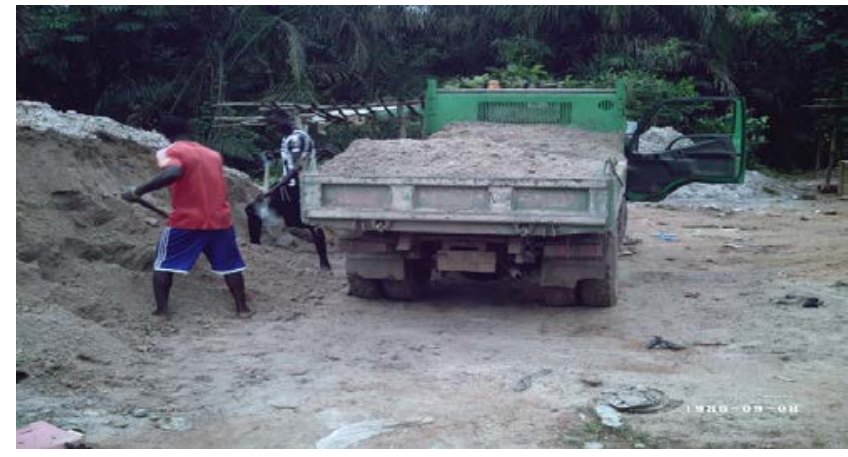

Figure 4. A truck being loaded with partially extracted tailings from surface mining activities

\subsection{Restoration or Reclamation?}

Reclamation has been defined as the rehabilitation of disturbed areas resulting from surface or underground mining [20]. Reference [5] defines it as a process of making a piece of disturbed land fit for cultivation. [18] considers reclamation as a desirable and necessary remedy to return mined areas to acceptable environmental condition whether for resumption of the former use or for a new use. Its basic objective is to re-establish vegetation cover, stabilize the soil and water conditions at the site and restore the ecosystem [5,20]. Reclamation can be achieved through natural recovery, assisted restoration or a combination of the two. Natural recovery takes time and can be hastened if assisted [5].

The process of recovery is an on-going activity [18], requiring time and effort; between 5 and 10 years to achieve any significant effect [5]. This paper however favours a combination of assisted and progressive reclamation [13]. Progressive reclamation is best suited to small scale surface mining as is common in Ghana, because it allows for reclamation following the depletion of minerals in one sector of the concession while other sectors are mined. Thus materials from newly opened areas can be transported and used to reclaim abandoned sites.

References [14,15] had observed that drastically disturbed soils are very difficult to re-vegetate mainly because of lack of fertile topsoil which is needed to provide nutrients, moisture, and a substrate for plant growth. Reclamation is thus aimed at improving the nutrient levels of the soil, especially nitrogen, which should be improved to at least $1000 \mathrm{kgha}^{-1}$ to ensure sustainable plant life [5]. This is best achieved through the introduction of fertile topsoil, use of nitrogen fixing legumes and establishment of tree plants [5]. The replacement and retention of topsoil combined with various means to sustain fertility is very important and may be the only way to achieve successful reclamation [5].

The topsoil is natural soil extracted from original surface layer of soils from grasslands, bush-lands or cultivated land [15]. It can also be obtained at the mine site or from nearby bushes with a small fraction of organic matter [15]. The organic matter component may be from pieces of wood or leaf matter which is mixed with the soil during the removal of the overburden. Alternatively, composted organic matter may be used. This may be imported into the site and incorporated into the soil to improve fertility, structure for moisture conservation and aeration as well as add to growth and vigor of planted seedlings [17].

The use of composted organic matter will help reduce demand on natural soil resources, whose extraction also has its own negative environmental consequences [15]. Composted organic matter used as a substitute should be of the highest quality in terms of stability and maturity. Reference [1] explains that a mature compost will have a high growth potential and will be fit for land application. A stable compost will resist any further decomposition and will have high organic matter to improve structure and build microbial biomass in the soil [6]. Although [5] does not support the use of fertilizer in the process of reclamation as it adds to cost, [14] thinks otherwise, arguing that some initial additions may be necessary to improve the nutrient status of the soil for effective plant growth. Both however agrees to a natural nutrient replenishment either through incorporation of composted organic matter [14] or use of leguminous cover crops which can help accumulate nitrogen in the soil [5], provide cover to protect the soil, help improve physical, chemical, and biological activity in the degraded soil [10]. This however has its own limitations as soils deficient in phosphorous and potassium cannot be replenished by either method and will require fertilizer application.

The establishment of the initial vegetation is the most important aspect of the process of reclamation but the condition of the soil will determine how fast the vegetation will establish [14]. Also the initial cover provides the first stage of succession on the reclaimed site [14] and should be made of leguminous cover crops like sunnhemp, centrosema, pueraria to precede woody species which will promote long term ecosystem processes [18] by improving fertility and microbial activity [16].

Trees are preferred for reclamation because of their wider adaptation to various soil types and will easily survive on degraded sites [11]. Some tree types like Leucaena, Gliricidia, and Acasia are nitrogen fixing and are ideal for aforestation of degraded sites [18]. However, selecting species which can enhance the nitrogen fixing capacity of plants will expedite the successional progress of a site [14]. Such trees should have high rate of leafy biomass production, a dense network of fine roots, with a capacity for abundant mycorrhizal association, a well developed taproot system and a capacity to grow on poor soils [18].

Depending on the desired end result of reclamation, natural recovery, assisted recovery or a combination of the two can be adopted in any reclamation exercise. Where a forest type of land-use is desired, natural recovery will be best but where a mixed use or agricultural use is intended, then the assisted type will be most appropriate. In either case the measure of success will depend on the intended end-use; whether for forest type in which case the number of species or its richness or where agricultural, then crop yield will be the best criteria for success [5].

\subsection{Re-vegetation of Mined Site}

Re-vegetation in a reclamation exercise is effective where native multiple species including ground covers and 
trees are used [20], mainly because they are better adapted, and can sustain a greater biodiversity [19]. Reference [18] however suggests the use of exotic species because they are faster growing. Sites to be reclaimed should attain a very good nitrogen status to support plant growth thus interventions should aim at building the soil to promote plant health [8]. To achieve this cover crops which also serve as the initial pioneering herbaceous species like centrosema, Sunnhemp (Crotalaria juncea) are broadcasted on the already prepared land [14,16]. This also serves as a soil cover to prevent erosion. Tree planting comes next after the cover crops have been worked into the soil [18].

The process of reclamation begins with earth works and slope battering. This is needed to achieve a visual blend of the disturbed area and the nearby undisturbed land. During the process slopes are battered to angles not exceeding $30^{\circ}$ [18] to ensure stability, and excavated areas filled out to the same level as the surrounding land; allowing for settlement. The filled out area should not be compacted but allowed to settle naturally and this may require 36months. After the filled out area has sufficiently settled, the next activity will be importation and spread of topsoil which should be supplied in bulk to the site [15]. The topsoil should be spread to a depth of $150 \mathrm{~mm}$, allowing a settlement differential of about $50-75 \mathrm{~mm}$. Application of topsoil to greater depths may not be beneficial to plants due to putrefaction of organic matter at the lower depths.

A minimum of two weeks should be allowed after the spread of the topsoil for settlement after which a suitable cover crop; leguminous with nitrogen fixing ability should be planted. The cover crop could be annual or perennial, however perennials are preferred as they can produce abundant biomass which could be cut periodically and used to mulch the land [10]. The planting of the cover crop should be done using seeds broadcasted evenly over the entire site [16]. The process may be repeated over areas which experienced poor germination to ensure continuous cover for the site. It may be necessary to apply a nitrogen fertilizer to improve soil fertility for the cover crops, after establishment.

About three months after sowing of the seeds when the cover crop is in flower, the entire field is cut and the cover crop worked into the soil using manual means or a plough (disc plough, mould-board plough, or harrow). At this stage it may be necessary to again apply a nitrogen based fertilizer to facilitate the process of decomposition and prevent nitrogen starvation. About three weeks after, when the incorporated organic manure has decomposed, the entire field could be pegged and planted with selected mix of native or exotic tree seedlings. The selected tree seedlings should have qualities like nitrogen fixing, extensive leafy biomass production and others, as described earlier and should be planted to a minimum of 450 seedlings per acre [2]. As explained earlier it is beneficial to encourage some amount of natural regeneration in any reclamation activity where native woody plant species are allowed to naturally re-vegetate the site alongside transplanted exotic tree seedlings. This can be achieved especially where top soil rich in native tree seeds is obtained from adjacent boundary to the mined site. Also where the site is close to a natural habitat, seed dispersal from the adjoining site will ensure fast colonization [11]. In a situation where the mined site is located far from any natural habitat, the best option will be to use mainly exotic tree plants.

\subsection{Community Participation Alternative Resource Development}

Mining companies currently employ local communities in various stages of their reclamation effort. This includes weed control, fire control, supply of native seedlings, seedling establishment and maintenance of reclamation sites and soil conservation [18]. To enhance or broaden community participation it may be necessary to encourage communities to establish community nurseries or private nurseries located in affected communities. While this creates employment for the communities it will also provide opportunity for them to part-take in the success or otherwise of the reclamation programme. The community members may be trained in the germination of easy to propagate indigenous tree plants in addition to exotic woody and non-woody plants. The community could also be trained in commercial compost production which can be sold to miners for reclamation. This can easily be done as most communities produce enough waste that can be composted to make a living. The later suggestion is particularly important as obtaining topsoil from surrounding bushes and grass lands for reclamation is not sustainable with its own environmental challenges as discussed earlier.

\subsection{Management of Reclaimed Site}

Every process of restoration must include plans for the management and monitoring of invasive plants until the preferred habitat has been established [11]. This is very important as invasive alien species can easily dominate and stress developing native plants, thus the need for monitoring.

\subsection{Cost Implication}

The importation of topsoil to the site could hinder the process of reclamation as this will be too expensive for most miners to afford. It is therefore necessary to secure sufficient room for a reclamation setback which will ensure that enough topsoil could be gathered from adjoining land for the reclamation effort. This should be combined with appropriate storage of the top soil. Soil amendments like compost, produced from the community will also help reduced the cost of fertilizer for the reclaimed land.

Table 1. Estimate for the cost of reclamation of 1 acre of land

\begin{tabular}{|c|c|c|c|c|c|c|}
\hline Item & Description & Quantity $/ \mathrm{m}^{3}$ & Qtty/Acre & $\begin{array}{c}\text { No Of Trips } \\
\left(15 \mathrm{~m}^{3}\right)\end{array}$ & $\begin{array}{c}\text { Cost } \\
(\mathrm{Gh} \Phi) / \mathrm{m}^{3}\end{array}$ & $\begin{array}{c}\text { Cost } \\
(\mathrm{Gh} \Phi) \\
\end{array}$ \\
\hline Subsoil $^{1}$ & $\begin{array}{c}\text { Spread in } 150 \mathrm{~mm} \text { layer to } 900 \mathrm{~mm} \\
\text { depth }\end{array}$ & 1.035 & 4188 & 321 trips & 7.98 & 33,440 \\
\hline
\end{tabular}




\begin{tabular}{|c|c|c|c|c|c|c|}
\hline Topsoil $^{2}$ & $\begin{array}{l}\text { Spread to } 200-225 \mathrm{~mm} \text { depth with } \\
15 \% \text { losses }\end{array}$ & 0.258 & $1047 \mathrm{~m}^{3}$. & 81 trips & 53 & 55600 \\
\hline $\begin{array}{c}\text { Harrowing and ploughing } \\
\text { Seeding } \\
\text { (Crotalaria juncea) } \\
\text { Sunnhemp }\end{array}$ & Seeding by broadcast & & $\begin{array}{l}40 / \text { day } \\
20 \mathrm{~kg}\end{array}$ & & & $\begin{array}{c}40 \\
180^{*}\end{array}$ \\
\hline \multirow{3}{*}{ Tree $^{4}$ planting } & Tree seedlings supply & $1.4 / \mathrm{m} 2$ & 563 & & 3Gh $\$ /$ plt & 1689 \\
\hline & Pegging and digging of tree pits & 1.4pegs $/ 10 \mathrm{~m}^{2}$ & 563 & & $0.5 \mathrm{Gh} \Phi / \mathrm{peg}$ & 281.5 \\
\hline & Planting & & & & & 540 \\
\hline $\begin{array}{c}\text { Allow } 2-3 \% \text { post planting } \\
\text { maintenance }\end{array}$ & & & & & & $\begin{array}{c}91,770.5 \\
9,177 \\
\end{array}$ \\
\hline Total & & & & & & $\begin{array}{c}100,947.5 \\
\text { (US } \$ 53,187.1)\end{array}$ \\
\hline
\end{tabular}

Assumption A:

1. A $15 \mathrm{~m}^{3}$ capacity truck will need 20trips max per day at 1000Gh $\$$ /day for 16days with a truck loader also @ 1000Gh $\$$ /day inclusive labour for truck drivers. Spreading of subsoil to a depth of $900 \mathrm{~mm}$ minimum using dozers or graders@1000Gh\$/day for 4days inclusive labour for operators to grade land to right falls

2. Spreading of topsoil by grader for 5days @ Gh\$1000/day followed by fertilizer application by broadcasting. Fertilizer application may be optional depending on soil fertility level

3. Seeding- includes sowing by broadcasting using spreaders (estimate not accurate) and inoculating seeds with a rhizobia inoculants to improve nitrogen fixing ability of the plant

4. Tree planting by 7 plants-men with 3 labourers at 40seedlings per day.

(Note: Gh $\$ 1000=$ US $\$ 526.9$ )

Assumption B:

This paper does not consider the cost of soil tests conducted at the initial stage of mining, as it is among the basic requirements for the mining of any piece of land in Ghana.

\section{Conclusion}

From the foregoing, it can be concluded that small scale surface mining has come to stay but must be streamlined and encouraged to be more economical and responsible. Although small scale miners operate over a relatively small area compared to multinational mining companies, their combined effect and the large number of people engaged in the industry could have a devastating effect on the environment. There is therefore the need to ensure continued production in a sustainable environment where mined concessions are reclaimed. However the process of reclamation should be managed in a way that ensures a win-win situation for the miners, the communities affected and the environment.

\section{Acknowledgement}

I wish to express my appreciation to Prof. (Nana) S.O. Apori, Head of the Animal Science Dept, University of Cape Coast for his encouragement in the preparation of this document.

\section{References}

[1] Al-Turki, A.I. "Quality Assessment of Commercially Produced Compost in Saudi Arabia Market”. International Journal of Agricultural Research. 5(2):70-79. 2010.

[2] Anonymous "Surface and underground Mining". Indiana Department of Natural Resources, 2012. www.in.gov/dnr/reclamation/3565.htm [10/07/12].

[3] Anonymous. Draft national Mining policy of Ghana 2010. http://www.ghanamining.org/GhanaIMS/LinkClick.aspx?fileticket=LmHT9VRIclI \%3D\&tabid=36\&mid =930 [12/07/12].

[4] Aryee, B.N.A., Ntibery, B.K. and Atorkui, E. "Trends in the Small-scale Mining of precious minerals in Ghana: A perspective on its environmental impact”. Journal of Cleaner production. (11) 131-140. 2003.

[5] Bradshaw, A.D. "Underlying Principles of Restoration”. Canadian Journal of Fisheries and Acquatic Science. 53 (Suppl. 1): 3-9. 1996.

[6] Cockcroft, B. “Orchard Soil management”. No 31. Our quest for the super soil. 2002.

www.fgv.com.au/Downloads/Grower\%20Info/SOIL/Soils31.pdf [08/10/09]

[7] Department of Water Affairs and Forestry. Best practices Guidelines - A1. Small scale Mining. Department of Water Affairs and Forestry. Pretoria. p1-3, 7-16. 2006.

[8] Diver, S. and Greer, L. "Sustainable Small Scale Nursery Production". ATTRA National Sustainable Agriculture Information Service. 2008.

[9] Duerr, T., Salzer, T., and Bromley, J. "Surface Reclamation programme". Division of Geology and Earth Resources. Washington State Dept of Natural Resources. Olympia. 2012.

[10] FAO. Green manure/cover crops and crop rotation in conservation agriculture on small farms. Integrated Crop management Vol. 12. p9, 60-61. Rome. 2011.

[11] Handel, S.N. "Restoration Ecology: Processes to advance Natural Landscape Restoration". Honors Award. American Society of Landscape Architects (ASLA). 2009.

[12] Hilson, G. A Contextual Review of the Ghanaian Small-Scale Mining Industry No. 76. "World Business Council for Sustainable Development (WBCSD). International Institute of Environment and Development”. England. p 5-16. 2002.

[13] Norman, D.K., Wampler, P. J., Throop, A.H., Schnitzer, E.F. and Roloff, J.M. "Best Management practices for Reclamation of Surface Mines in Washington and Oregon”. Washington Division of Geology and Earth Resources. Washington State Department of Natural Resources. Olympia. 1997.

http://www.dnr.wa.gov/businesspermits/topics/miningenergyresou rceregulation/pages/smr.aspx [10/07/12].

[14] Polster, D.F "Natural Vegetation Succession and Sustainable Reclamation". Proceedings of the 15th Committee on Reclamation. Technical and Research. Annual British Columbia Mine Reclamation Symposium in Kamloops, BC p 59-69. 1991.

[15] Recycled Organics Unit (ROU), 4th Ed. "Manufacturing Quality Products for Compost". Introduction to Australian Standards AS 4419-2002 Soils for Landscaping and Garden Use. Information Sheet No 3-10. Recycled Organics Unit. 2012. www.recycledorganics.com/infosheets/3pqc/IS3-10.pdf [23/12/12]

[16] Sangakkara, U.R., Weerasekera, D.N. and Freyer, B. Green Manuring for tropical organic cropping- A comparative analysis. 16th IFOAM Organic World Congress, Modera, Italy. June 16-20, 2008.

[17] Singh, J. Basic Horticulture. Kalyaris Publication. New Delhi. p65

[18] Tetteh, E.N. "Evaluation of land Reclamation practices at AngloGold Ashanti; Iduapriem Mines Ltd, Tarkwa”. MSc Thesis. 
Kwame Nkrumah University of Science and Technology, Kumasi. P 19-44, 78-84, August. 2010.

[19] TCPA, "Biodiversity by Design: A guide for Sustainable Communities”. Home and Communities for Sustainable Future. Town and Country Planning Association. London. P 6-8. 2004.
[20] Yelpaala, K. "Mining, Sustainable Development and Health in Ghana: The Akwatia Case Study” Kaakpema Yelpaala. 2004. 